\title{
Changing the Course: Interpreting and Structuring Scientific Texts Aided by ICT
}

Cambio de curso: interpretación y elaboración de textos científicos con la ayuda de TIC

Mudando o curso: interpretando e estruturando textos científicos com o auxílio de NTIC

Rigoberto CASTILLO

orcid.org/0000-0002-2558-5178.

Universidad Distrital Francisco José de Caldas, Colombia. rcastillo@udistrital.edu.co

Received: 2017-08-22

Accepted by peers: 2017-12-03
Send to for peer review: 2017-12-01

Approved: 2018-01-10

To reference this article in APA style / Para citar este artículo en APA / Para citar este artigo Castillo, R. (2017). Changing the course: Interpreting and structuring scientific texts aided by ICT. Latin American Journal of Content and Language Integrated Learning, 10(2), 245270. doi:10.5294/laclil.2017.10.2.4 
ABSTRACT. Changes to the pedagogy of foreign languages (FL) have taken place with the integration of Information and Communication Technologies (ICT). These changes provide instructors with opportunities to become meaning facilitators and designers. This article presents the rationale behind the pedagogy for a university course to enhance FL for academic purposes. It refers to three editions of a course with around 15 students each, native speakers of Spanish who self-assessed as being in an A2 to B1- English proficiency level in the scale of the Common European Framework of Reference. They came equipped with disciplinary knowledge in education and needed to build the state of the art of their research proposals. They submitted an account of up-to-date literature and research reports. The course, aided by ICT, helped them search, find, understand and integrate to their projects valuable literature available in English and in Romance languages. Students drafted their research interest in English and prepared an oral presentation. The needs of the FL learners were better served for they were directly connected to what they do at the university, which is, among other things, to determine the quality and authority of the sources and therefore interpret and assess texts related to their field of expertise. The article proposes moving away from a focus on language to a focus on problem solving and presents strategies, procedures, and ICT support. The article problematizes the issue of proficiency defined in terms of the type of problems language users could solve to meet their needs rather than in terms of language level.

\section{Keywords: Academic writing; genre; ICT; strategic language learning; syllabus design; university.}

RESUMEN. Se han realizado cambios en la pedagogía de las lenguas extranjeras (LE) a través de la integración de las tecnologías de la información y la comunicación (TIC). Estos cambios les brindan a los instructores oportunidades para convertirse en facilitadores y diseñadores de significado. Este artículo presenta los fundamentos o la razón fundamental de la pedagogía para un curso universitario a fin de mejorar las LE con fines académicos. Hace referencia a tres versiones de un curso con cerca de 15 estudiantes cada uno, todos hablantes nativos de español que se autoevaluaron en un nivel de competencia en inglés entre A2 y B1, en la escala del Marco de Referencia Común Europeo. Venían preparados con conocimiento disciplinario en educación y necesitaban construir sus propuestas de investigación a un máximo nivel. Presentaron una relación de literatura actualizada e informes de investigación. El curso, con el apoyo de las TIC, les ayudó a buscar, encontrar, comprender e integrar a sus proyectos una parte de literatura valiosa disponible en inglés y en lenguas romances. Los estudiantes redactaron una descripción de su interés en la investigación en inglés y prepararon una presentación oral. Las necesidades de los alumnos de LE fueron mejor atendidas, ya que estaban directamente conectadas con lo que hacen en la universidad, que es, entre otras cosas, determinar la calidad y la autoridad de las fuentes y, por lo tanto, interpretar y evaluar textos relacionados con su campo de especialización y experiencia. El artículo propone pasar de un enfoque en el lenguaje a un enfoque en la resolución de problemas y presenta estrategias, procedimientos y soportes de las TIC. El artículo problematiza la cuestión de la competencia definida en términos del tipo de problemas que los usuarios del lenguaje podrían resolver para satisfacer sus necesidades en vez de en términos de su nivel en el idioma.

Palabras clave: escritura académica; género; TIC; aprendizaje estratégico de idiomas; diseño del plan de estudios: universidad.

RESUMO. Mudanças na pedagogia das línguas estrangeiras (LE) ganharam espaço com a integração de Novas Tecnologias de Informação e Comunicação (NTIC). Tais mudanças oferecem aos instrutores oportunidades de se tornarem designers e facilitadores de significado. Este artigo apresenta a fundamentação por trás da pedagogia para um curso universitário de aprimoramento da LE para propósitos acadêmicos. Refere-se a três edições de um curso com cerca de 15 estudantes cada um, falantes nativos de espanhol que se autoavaliaram com um nível de proficiência de inglês de A2 a B1, na escala do Quadro Europeu Comum de Referência. Eram estudantes capacitados com conhecimento disciplinar em educação e precisavam construir o estado da arte de seus propósitos de pesquisa. Eles entregaram uma série de relatórios de literatura e pesquisa atualizados. O curso, com o auxílio de NTIC, ajudou-os a buscar, encontrar, entender e integrar literatura de relevância disponível em inglês e em línguas românicas a seus projetos. Os estudantes delinearam seus interesses de pesquisa em inglês e prepararam uma apresentação oral. As necessidades dos alunos de LE foram satisfeitas de forma mais acertada porque elas estavam diretamente conectadas ao que eles fazem na universidade, que é, entre outras coisas, determinar a qualidade e a autoridade das fontes e, portanto, interpretar e analisar textos relacionados à sua área de conhecimento. O artigo propõe deixar de focar no idioma e passar a focar na solução de um problema e na apresentação de estratégias, procedimentos e apoio de NTIC. O artigo problematiza a questão da proficiência definida em termos do tipo de problemas de linguagem que os usuários puderam resolver para atender suas necessidades em termos de nível de idioma.

Palavras-chave: criação de programa; escrita acadêmica; ensino estratégico do idioma; gênero; NTIC; universidade. 


\section{Introduction}

Societies have recognized that languages play an important role in academia for cooperation, mobility, and internationalization. In Colombian universities, policies, requirements and attitudes toward foreign language (FL) study have been the subject of reflection. University alumni are expected to achieve an intermediate level (B1), and yet the results seem far from that goal (see M.E.N, 2015, pp. 19-23) (Granado; 2013; Castillo \& Pineda-Puerta, 2016). For The Ministry of Education (M.E.N, 2015) the pedagogical model is one of the factors that accounts for success in English language learning in higher education; the other factors being the teachers, the culture of evaluation of learning and the supporting infrastructure. This paper addresses the pedagogical model.

I have taught several courses following the pedagogical model of Strategic Learning, which, briefly described, stresses on procedures, strategies, and resources to solve a problem (Castillo, 2014). In this case, the problem posed is the path to access and assess primary quality literature and the interpretation and elaboration of scientific texts. This pedagogy attempts to be sensitive to the readers' and writers' intentions, purposes, and use of strategies, and, more importantly, to the expression of their voice. This contrasts with approaches in higher education that stress language study, language development (c.f., Castelló, Mateos, Castell, Iñesta, Cuevas, \& Solé, 2012) and rhetoric (Kent, 2012). Similarly, the Process-Oriented and Product-Oriented approaches fall short in coping with the demands and expectation of conducting an inquiry in the digital era. Practitioners will find here ideas to plan, execute and assess learning framed in in a syllabus using scholarly literature and designed with a localized pedagogy that uses electronic environments to find, draft, revise, edit, and share texts. This enriches research projects with the most valuable concepts found in the literature.

The paper opens with the context, followed by a rationale for a syllabus proposal which brings representative tasks and ICT aids. Then, a sample of the work of a graduate student illustrates the rubrics and the task sequence. It closes with a discussion of the learners' achievements attributable to the teaching approach proposed. 


\section{Context}

The paper refers to a graduate program in education in Bogotá which aims at advancing knowledge to achieve a high level of academic excellence in scientific research that contributes to the solution of problems of the educational sector. To obtain their degree, students must demonstrate an upper intermediate level of a FL, which they take as an elective course. In the course, students displayed information-seeking skills in the first language, which did not seem to transfer to the FL.

The notion of academic literacy in higher education usually goes hand in hand with language proficiency level. In contrast, the course proposed here took advantage of the disciplinary knowledge students already had in the first language to tackle the FL, making the most of their capacity to make meaning from scholarly sources and from media that bring multimodal texts, which integrate other modes of reading and writing. For instance, databases, tutorials and other ICT tools assisted students in finding, interpreting, assessing, and using works relevant to their research interest, both in English and in Romance languages (see task 3 in Table 1 and in the appendix).

The syllabus drew on strategic language learning (Castillo, 2014; Oxford, 1990, 2013; O'Malley \& Chamot, 1990), on genre analysis (Swales, 1990, 2004; Hyland, 2004, 2007; and Devitt, 2015). It also contemplated multiliteracies (Cope \& Kalantzis, 2009, Iyer, 2007, and Klimova, 2011). The underlying assumption being that the practice of strategies, the familiarization with academic genres and the mediation of the multiliteracies, in print and in the World Wide Web, expand thinking.

The following section explains the rationale behind the course aided by ICT; it describes the syllabus implemented and provides samples of the students' work. The author invites readers to rethink foreign language teaching as localized problem- solving to better serve the needs of academia at a time when ICT are readily available.

\section{Syllabus proposed}

In order to comply with the goals of the Ministry of Education of Colombia, universities offer general English courses, English for academic purposes, or English for specific purposes. Granados (2013), for instance, 
presents a syllabus and an approach of a university in Bogotá that attempts to balance general and specific content. They decided to...

establish a solid link between English and disciplinary areas, finding content area teachers willing to make a joint effort with language teachers in order to strengthen instruction not only in the content area, but also in the use of English for learning that content. (Granados, 2013, p. 250)

The syllabus presented here goes a step beyond, for it tries to enable EFL learners to strengthen their library and database search skills, to evaluate sources and documents, to express their own voice in polyphony with other voices, and more importantly, to build their confidence in disseminating the knowledge they produce.

Academic literacy for scientific purposes has deserved attention in the literature. Devitt (2015) argues that, "although the disciplines differ in some of their purposes and settings, they share the difficulty of helping students advance beyond simplified understandings of genre to the complex decisions needed to address particular situations" (p. 44). The concern of the syllabus for the university course was to offer English communication for scientists covering topics such as the understanding of papers, drafting papers, interacting with diverse audiences and presenting their work. For that reason, in the syllabus proposed here, learners became familiar with the characteristic of the genre academic paper and of some subgenres (e.g., abstract, introduction, or literature review) to express their original research ideas.

This led learners to better choose, interpret and evaluate the authority, accuracy, objectivity and relevance of the sources, for example by identifying the most cited author in a topic. It trained the students to assert the writers' positions, as well as to assert their own with cautious language, thus paving the way to draft texts of their discipline in the FL. For closing the course, the graduates peeked into the video resources for doctoral students produced by The Education University of Hong Kong (2016) in which supervisors and students talk about on a particular aspects of a research process in education.

As the teaching approach was introduced, it transformed practices and contributed to give individuals a sense of autonomy. Thus, the course included authentic learning and authentic task design, like 
the ones in Table 1 and in Appendix 1. The course abode by these principles, materialized in the syllabus proposed: First, reading and writing are developmental—as learners master procedures, strategies, ICT tools, and resources, they become capable of overcoming problems of search, selection, interpretation and production of texts in a FL. Second, to become efficient users of the FL, they needed to build up processes to generate, organize, and edit ideas, as well as to look for coherence and cohesion. Third, course participants share and debate their interpretative and creative processes. Fourth, in both classroom and computer lab tasks the students become familiar with the conventions of diverse academic genres such as abstracts, reviews, reports, books, and oral presentations (c.f., Trenado, 2004; Peretz, 2005; Ibáñez, 2007). In those spaces, participants conducted database search and worked on references and citations. Table 1 shows the syllabus outline to illustrate the arguments made so far.

Instruction in selecting, interpreting, assessing and producing texts around a research interest aimed at developing the graduate students' English while enhancing their research work, especially the state of the art, and prepared them to present their thesis to broader audiences. The scaffolded tasks proposed by the instructor headed to meet the goal: Use reading and writing processes to explore, think, and learn, and to write appropriately for various tasks and audiences.

Table 1. Syllabus for interpreting and drafting scientific texts aided by ICT

\begin{tabular}{|c|l|l|}
\hline WEEK & \multicolumn{1}{|c|}{ OBJECTIVES } & \multicolumn{1}{c|}{ TASKS } \\
\hline 1 & $\begin{array}{l}\text { Introduction: Strategic } \\
\text { knowledge and language } \\
\text { learning. } \\
\text { Select titles and keywords }\end{array}$ & $\begin{array}{l}\text { Task 1. Translate to English the title } \\
\text { of your thesis. Then run a computer } \\
\text { search to identify key words and to } \\
\text { make a glossary of your research topic. }\end{array}$ \\
\hline 2 & $\begin{array}{l}\text { Building up processes to } \\
\text { distinguish the rhetorical } \\
\text { organization and the } \\
\text { moves of a research paper }\end{array}$ & $\begin{array}{l}\text { Task 2. General discussion of a } \\
\text { research paper. Identify sections, } \\
\text { organization, tone and style. }\end{array}$ \\
\hline 3 & $\begin{array}{l}\text { Building up processes to } \\
\text { generate ideas: Identifying } \\
\text { and interpreting abstracts }\end{array}$ & $\begin{array}{l}\text { Task 3. Search in academic databases } \\
\text { abstracts closely related to your } \\
\text { research topic. Decide on the authority } \\
\text { of the source and of the relevance to } \\
\text { your purposes. }\end{array}$ \\
\hline
\end{tabular}




\begin{tabular}{|c|c|c|}
\hline 4 & $\begin{array}{l}\text { Building up processes to } \\
\text { organize ideas. Analyzing } \\
\text { the Introduction of an } \\
\text { academic paper }\end{array}$ & $\begin{array}{l}\text { Task 4. Interpret texts. Use ICT } \\
\text { support: word clouds, graphic } \\
\text { organizers, the mouse right button, } \\
\text { on-line dictionaries, on-screen notes, } \\
\text { highlighters, etc. }\end{array}$ \\
\hline 5 & $\begin{array}{l}\text { Building knowledge } \\
\text { of how arguments are } \\
\text { developed and presented } \\
\text { in a field. Assessing a } \\
\text { research report }\end{array}$ & $\begin{array}{l}\text { Task } 5 \text {. Read the full text of a research } \\
\text { report of your choice and summarize } \\
\text { it to the class. Stress the authority of } \\
\text { the sources and the relevance to your } \\
\text { thesis. }\end{array}$ \\
\hline 6 & $\begin{array}{l}\text { Inferring the function } \\
\text { of paragraphs and of } \\
\text { paragraph transitions }\end{array}$ & $\begin{array}{l}\text { Task } 6 \text {. Analyze the function of each } \\
\text { paragraph of a paper provided in } \\
\text { class. }\end{array}$ \\
\hline 7 & $\begin{array}{l}\text { Explaining the } \\
\text { organization and rationale } \\
\text { of rhetorical moves }\end{array}$ & $\begin{array}{l}\text { Task } 7 . \text { Identify the moves the writer } \\
\text { makes in each section of the paper. } \\
\text { Use of dictionaries of collocations. }\end{array}$ \\
\hline 8 & $\begin{array}{l}\text { Building up processes to } \\
\text { edit ideas. Summarizing } \\
\text { and interpreting }\end{array}$ & $\begin{array}{l}\text { Task 8. Submit report and discuss } \\
\text { another research report you read in } \\
\text { English. You may use either Spanish or } \\
\text { English in your text. } \\
\text { - Discussion on avoiding plagiarism. }\end{array}$ \\
\hline 9 & $\begin{array}{l}\text { Knowledge of how to } \\
\text { assess, interpret and } \\
\text { critique ideas. Assessing } \\
\text { and critiquing }\end{array}$ & $\begin{array}{l}\text { Task 9. Submit a report in Spanish or in } \\
\text { English of a doctoral thesis you read in } \\
\text { English. As you do that, make notes on } \\
\text { the coherence of the argumentation. }\end{array}$ \\
\hline 10 & $\begin{array}{l}\text { Analyzing the effort } \\
\text { required in the elaboration } \\
\text { of thought and argument } \\
\text { in an academic } \\
\text { assignment: Reading and } \\
\text { appraising a book }\end{array}$ & $\begin{array}{l}\text { Task 10. Submit a critical review in } \\
\text { Spanish or in English of a book - } \\
\text { related to your thesis- that you read in } \\
\text { English. } \\
\text { Generate references and citations } \\
\text { using MSWORD. }\end{array}$ \\
\hline 11 & $\begin{array}{l}\text { Examining the status of } \\
\text { ideas and arguments } \\
\text { e.g. as fact, hypothesis, } \\
\text { opinion or beliefs }\end{array}$ & $\begin{array}{l}\text { Task 11. Apply the University of Virginia } \\
\text { (2014) template to draft in English the } \\
\text { problem statement of your thesis. }\end{array}$ \\
\hline 12 & $\begin{array}{l}\text { Connecting ideas while } \\
\text { maintaining a rigorous } \\
\text { approach to the analysis } \\
\text { of arguments and } \\
\text { propositions }\end{array}$ & $\begin{array}{l}\text { Task } 12 \text {. Consult the U.S.C library } \\
\text { guide and others to draft in English the } \\
\text { abstract of your thesis. } \\
\text { Search a video lecture related to your } \\
\text { topic. }\end{array}$ \\
\hline 13 & Recapitulation (continued) & $\begin{array}{l}\text { Task 13. Consult the U.S.C library } \\
\text { guide and others to draft in English a } \\
\text { brief Introduction of your thesis. }\end{array}$ \\
\hline
\end{tabular}




\begin{tabular}{|c|c|c|}
\hline 14 & $\begin{array}{l}\text { Understanding academic } \\
\text { presentations }\end{array}$ & $\begin{array}{l}\text { Task 14. Analyze the organization, the } \\
\text { form and the delivery of an academic } \\
\text { presentation provided in class. ICT } \\
\text { medial: Ted.com. }\end{array}$ \\
\hline 15 & $\begin{array}{l}\text { Preparing and delivering } \\
\text { a scientific presentation } \\
\text { of your research interest: } \\
\text { Title, keywords, abstract, } \\
\text { introduction, literature } \\
\text { review and problem } \\
\text { statement plus a reference } \\
\text { section }\end{array}$ & $\begin{array}{l}\text { Task } 15 \text {. Write the script to make an } \\
\text { oral presentation in English to share the } \\
\text { purpose and the central ideas of your } \\
\text { thesis. Use PechaKucha Style format: } \\
20 \text { slides } \times 20 \text { seconds each. } \\
\text { Rehearse by using an ICT tool Text-to- } \\
\text { Speech. }\end{array}$ \\
\hline 16 & Feedback session & $\begin{array}{l}\text { Look up: The Education University of } \\
\text { Hong Kong (2016). Video Resources } \\
\text { for Doctoral Students. }\end{array}$ \\
\hline
\end{tabular}

Source: Own elaboration.

To achieve the course goal, contents and instructions illustrated so far, call for developing awareness of:

a. The rhetorical organization and the rhetorical moves of scientific texts (Swales, 2004);

b. Genres (Hyland, 2004, 2007; Swales, 2004);

c. Building glossaries, to support their efforts of communication in the FL; and

d. Language learning strategies for solving problems in connection with the FL (Oxford, 1990, 2013, Castillo, 2104).

Instruction aimed at supporting the search, understanding and production of texts in different formats and media. Sample papers and texts, and the application of ICT tools backed up a process of discovery in which learners moved through these phases: Generation of ideas, Organization of ideas, Edition of ideas, and Looking for coherence and cohesion.

The course situated research topics within a field and a subfield; students read and wrote about the broad issues and the narrow issue under scrutiny. They also analyzed the rhetorical organization of the works consulted. In a first draft, they explained how the sources functioned to shape what we know and how we know it, and needed to position sources informing the particular topic under examination. 
On the other hand, digital tools accelerated the bibliographical search, the selection, the interpretation of texts, and the drafting of new texts. Graduate students also shared other tools they were familiar with, which they either customized or to which they gave new uses. Appendix 2 provides a detailed description of some of the ICT tools that supported the development of the tasks. The readers interested in other ICT tools to do research and to write with may refer to Digital tools for researchers (2017).

Students carried out search tasks of the literature related to their inquiry and later followed models to write sections of their own paper. Table 1 exemplifies how tasks increased in complexity and how the syllabus scaffolded shorter assignments that led to a larger assignment. Similarly, the sample of a student's work in Table 2 illustrates the sequence to meet the goal of consulting, reading, and editing for drafting a thesis abstract. This table brings a sample of one of the graduates-with a low intermediate level in English-who works on the topic of biological evolution. Columns 1 and 3 show the guide provided in English and Spanish. The student's actual words appear unedited. The sequence offers a controlled practice to build the learners' confidence in using the target language while involved in presenting their research interest.

Task A uses the students' thesis as point of departure. They obtain a snapshot of their proposal with a word cloud (Wordle, 2016) and Wordsift (2017), while Task B helps them build the lexicon in the FL from their first language; in other words, they move from the known to the unknown, aided digital tools.

In Task C, students learnt a way to adapt the search engine to their needs of consulting it in English. In the computer lab, this exercise had been done for romance languages like Portuguese, Italian, and Catalonian to demonstrate that, aided with their disciplinary knowledge, they could get the gist of most of the literature.

In Task D, by scaffolding, learners built a glossary from academic sources while browsing publications for further reference. The sample indicates a good degree of awareness in which the graduate displays his position vis-à-vis the term chosen.

Task E led the learners' reading into semi-controlled writing. They generate ideas from their draft in Spanish and from the readings that 
they did in English. The template suggested contributes to organizing their ideas, while the grammar-spelling check aided accuracy. Task F scaffolds to a more complex text and a more complex task, which was the drafting in English the introduction of the theses in English.

Table 2. Sample of a student's work (unedited)

\begin{tabular}{|c|c|c|}
\hline $\begin{array}{l}\text { Guide provided in the } \\
\text { foreign language }\end{array}$ & $\begin{array}{c}\text { Graduate student } \\
\text { sample work }\end{array}$ & $\begin{array}{l}\text { Guide provided in the } \\
\text { first language }\end{array}$ \\
\hline $\begin{array}{l}\text { Dear Students: } \\
\text { We have covered } \\
\text { strategies, resources } \\
\text { and tools for reading } \\
\text { and writing. Please } \\
\text { carry out the following } \\
\text { tasks using them. }\end{array}$ & $\begin{array}{l}\text { Working title of thesis: } \\
\text { Circulation of the theory } \\
\text { of biological evolution in } \\
\text { primary and secondary } \\
\text { schools in Colombia. } \\
\text { Título tentativo de } \\
\text { la tesis: Circulación } \\
\text { de la teoría de la } \\
\text { evolución biológica en } \\
\text { la educación primaria } \\
\text { y secundaria de } \\
\text { Colombia. }\end{array}$ & $\begin{array}{l}\text { Estimados estudiantes: } \\
\text { Hemos trabajado } \\
\text { estrategias, recursos y } \\
\text { herramientas de trabajo } \\
\text { para la lectura y la } \\
\text { escritura. Utilizando lo } \\
\text { anterior, cordialmente } \\
\text { les solicito seguir los } \\
\text { pasos siguientes. }\end{array}$ \\
\hline $\begin{array}{l}\text { Task A. Enter Wordle. } \\
\text { net. Copy and paste } \\
\text { your thesis document } \\
\text { from the introduction } \\
\text { to the end, except the } \\
\text { bibliography. }\end{array}$ & 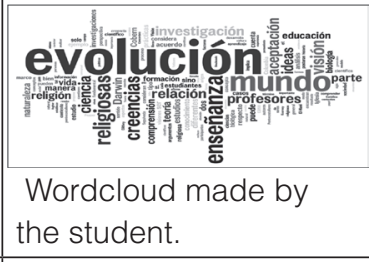 & $\begin{array}{l}\text { Ingrese a Wordle.net } \\
\text { o worsift.org y pegue } \\
\text { su documento de } \\
\text { avance de tesis desde } \\
\text { la introducción hasta el } \\
\text { final, sin la bibliografía. }\end{array}$ \\
\hline $\begin{array}{l}\text { Task B. Take ten } \\
\text { key words from the } \\
\text { generated cloud. } \\
\text { Translate them into } \\
\text { English and find their } \\
\text { definition in an online } \\
\text { dictionary. }\end{array}$ & $\begin{array}{l}\text { "Evolution: a theory that } \\
\text { the differences between } \\
\text { modern plants and } \\
\text { animals are because of } \\
\text { changes that happened } \\
\text { by a natural process } \\
\text { over a very long time." } \\
\text { Webster dictionary. }\end{array}$ & $\begin{array}{l}\text { De la nube de palabras, } \\
\text { generada por la nube } \\
\text { tome diez palabras } \\
\text { clave y páselas } \\
\text { a lengua inglesa } \\
\text { buscando en ese } \\
\text { idioma su definición. }\end{array}$ \\
\hline $\begin{array}{l}\text { Task C. Temporarily } \\
\text { customize the tool } \\
\text { Scholar.google.com. } \\
\text { Select English. Enter the } \\
\text { ten key words to search } \\
\text { for documents related to } \\
\text { your thesis. }\end{array}$ & $\begin{array}{l}\text { Scholar.google.com } \\
\text { presents more quality } \\
\text { literature than Google } \\
\text { alone. }\end{array}$ & $\begin{array}{l}\text { Personalice la } \\
\text { herramienta Google } \\
\text { académico en inglés } \\
\text { temporalmente. } \\
\text { Busque su tema de } \\
\text { investigación utilizando } \\
\text { las diez palabras clave } \\
\text { arriba identificadas. }\end{array}$ \\
\hline
\end{tabular}




\begin{tabular}{|c|c|c|}
\hline $\begin{array}{l}\text { Task D. As you read, } \\
\text { build up a glossary } \\
\text { with other ten terms } \\
\text { appearing recurrently in } \\
\text { the readings. }\end{array}$ & $\begin{array}{l}\text { It's worth noting that we } \\
\text { use the word evolution } \\
\text { to refer to biological } \\
\text { evolution. We don't use } \\
\text { evolution theory since it } \\
\text { is confusing, because } \\
\text { evolution is a theoretical } \\
\text { body, composed by } \\
\text { many theories. }\end{array}$ & $\begin{array}{l}\text { A medida que lee, } \\
\text { levante un glosario } \\
\text { de otros } 10 \text { términos } \\
\text { que encuentre } \\
\text { recurrentemente en su } \\
\text { tema. }\end{array}$ \\
\hline $\begin{array}{l}\text { Task E. Make a first draft } \\
\text { of the abstract of your } \\
\text { thesis. Do not translate; } \\
\text { instead put the key } \\
\text { words in sentences. } \\
\text { To organize ideas, } \\
\text { follow a guide on how to } \\
\text { write an abstract such } \\
\text { as the one found in: } \\
\text { http://libguides.usc.edu/ } \\
\text { writingguide/abstract }\end{array}$ & $\begin{array}{l}\text { "Abstract. The } \\
\text { project deals with the } \\
\text { relationship between the } \\
\text { religious beliefs and the } \\
\text { evolution teaching. The } \\
\text { evolution is a conceptual } \\
\text { system and an } \\
\text { intellectual movement. } \\
\text { For this reason to } \\
\text { understand its origin, } \\
\text { development, and } \\
\text { circulation is important } \\
\text { tackle the social and } \\
\text { cultural context..." }\end{array}$ & $\begin{array}{l}\text { Escriba en inglés un } \\
\text { primer borrador del } \\
\text { resumen (abstract) de } \\
\text { su tesis. No traduzca, } \\
\text { use las palabras } \\
\text { clave en frases. Para } \\
\text { organizar las ideas, siga } \\
\text { una guía para escribir } \\
\text { un abstract como: http:// } \\
\text { libguides.usc.edu/ } \\
\text { writingguide/abstract }\end{array}$ \\
\hline $\begin{array}{l}\text { Task F. In a separate } \\
\text { page, please draft } \\
\text { an introduction to } \\
\text { your thesis using the } \\
\text { above glossary and } \\
\text { the tool found at: http:// } \\
\text { libguides.usc.edu/ } \\
\text { writingguide/introduction } \\
\text { Before submitting your } \\
\text { work, edit it with a } \\
\text { grammar-spell check } \\
\text { tool, with Wordle, and } \\
\text { have a peer review it. }\end{array}$ & $\begin{array}{l}\text { * Introduction not } \\
\text { included due to length. }\end{array}$ & $\begin{array}{l}\text { Haga un borrador de la } \\
\text { introducción de su tesis. } \\
\text { Use el glosario y la guía } \\
\text { sobre cómo redactar } \\
\text { una introducción: http:// } \\
\text { libguides.usc.edu/ } \\
\text { writingguide/introduction } \\
\text { Antes de entregar el } \\
\text { resumen, edítelo con el } \\
\text { corrector ortográfico, } \\
\text { con Wordle y que lo } \\
\text { revise un compañero de } \\
\text { clase. }\end{array}$ \\
\hline
\end{tabular}

Source: Appendix 2.

Similar tasks, procedures and digital tools were exploited to lead graduate students to understand the rhetorical organization of an introduction, to become familiar with the subsections of introductions to a thesis, to draft an introduction, as in Task 6 of Table 2 and of the Appendix. They were tutored in how to run a search in English and how 
to filter the contents of academic databases. The course closed with an oral presentation of their proposal, following the PechaKucha style, in which presenters delivered a brief presentation with images and no text in 20 slides for 20 second each.

The course combined face-to-face interaction, the computer lab, and the Moodle platform. For Klimova (2011), learning environments have grown and expanded as new technologies have expanded the possibilities for distributed communication and interaction. The integration of ICT to the methodology drew from a view of communication as a complex landscape, in which language takes a different status in academic contexts and in multiple media. Multimodal resources offer a communicative potential in which the student can grasp or convey meanings not only by means of reading or writing, but by listening, viewing, and by operating on the information found like representing graphically. Iyer (2007) argues that:

In an era of multiliteracies, teaching and learning have become knowledge performances at multiple levels. Instead of a singular, linear focus upon print technologies, the techno-oriented philosophy of teaching aims at providing a rhizomatic network of texts where there is a close link between, and often an overlap of, different designs-linguistic, visual, spatial, and gestural - to construct the multiliterate learner (p. 2)

To illustrate how to serve the multiliterate learners, Appendix 1 gives an account of how some digital tools were consulted, applied or adapted.

\section{Discussion}

Changing the course from competency oriented to problem-solving followed these pedagogical tenets: The first relates to scaffolding; the course started with simple texts and simple tasks, like understanding or translating the title of a thesis. It followed with simple tasks and complex texts, such as reporting a research paper by identifying setting, population, length of study, method, and results. By the end of 
the course, the students worked on complex texts and complex tasks, such as writing a critical review of a book, and giving a structured oral presentation of their research project.

The second pedagogical tenet suggests that the syllabus design that involved controlled practice, semi-controlled, and free practice, assisted with ICT, proved useful. Controlled practice made use of templates and worksheets; semi-controlled practice included work with rubrics and checklists; and, the free practice meant writing a script of a timed oral presentation of their research topic (PechaKucha, n.d) and rehearsing it with a text-to-speech tool.

At the end of the course, students took a survey on what they had learned, what they would keep and what they would change. Their responses indicated that the syllabus promoted transfer of information seeking skills, and brought new practices about understanding another language for academic purposes. They agreed that detailed guidance, rubrics (see Table 2) reinforced their learning. For them, the generation of citations and references with Microsoft Word, which was new to many, was deemed a must for academia. They also stated that the sessions devoted to avoiding and preventing plagiarism proved very useful; we worked with Bailey (2011), who suggests preventing plagiarism by selecting key points, note-making, paraphrasing, summarizing, and combining sources as well as by developing good study habits.

The graduate students concurred that this was a course both in doing research and in putting it into writing; this means that the awareness they gained activated deeper thinking. They also claimed that synthesizing information required the most work. After the course, the student, author of the sample in the Appendix, did an internship in Holland and affirmed that the course had actually prepared him to work with other scholars. Two graduate students, who were trained as librarians, felt quite impressed for they claimed they had found sources and publications they would not have been able to find, had it not been by this course in which they resorted to other languages to run their search. Another student found a research group from Scandinavian countries with important publications on her topic. Others have participated confidently in conferences and publications in which English is the means of communication. 


\section{Conclusion}

The syllabus designed supported with digital tools raised awareness of the effects of information seeking in another language. Graduate students agreed that finding new sources and new concepts enhanced their research proposals. They said that they felt assertive consulting literature in another language, and highlighted the friendly approach to the tasks, which took their previous knowledge as a point of departure. They affirmed that they realized that, in spite of their low English level, they were able to solve the problems at hand, such as establishing the authority of a source, finding up-to-date literature in their field, reading efficiently in a FL, and deciding if a text found was worth being read intensively.

On the other hand, the syllabus, the contents and procedures of which are related directly to the graduates' inquiries, gave them a voice. They affirmed that drafting their project intelligibly to communicate it to wider audiences constituted a practical and satisfying way to approach the FL, since they were communicating the knowledge they attempted to produce.

As typified by the sample in Appendix 1, the students' knowledge of their topic helped them overcome the language barrier. They claimed that the work done on the information and on the sources enhanced conceptualization and exercised a very positive influence on comprehension and on production. They acknowledged that they developed awareness of the need to follow systematic procedures when reading and writing in the FL. Similarly, they realized that digital tools and applications greatly contributed to the quality of their work both in their own language as well as in the FL. This coincides with Marshall (2007), who claims that ICT "enhances the teaching and learning experiences of the students and the lecturer, students participate actively in the unit, interact and collaborate with each other and with the lecturer, and do so within a safe environment" (p. 109).

As for the limitations, the caveat for course developers consists in avoiding tasks, guides and other materials that reduce the student's work to a game of cut-and-paste, note taking or summarizing (Castelló et al., 2012). Instead, the course needs assist learners in finding their 
voice in and expressing their position to communicate their inquiries. To foreground the writer's argument without overreliance on sources requires practice and experience; the team work with the faculty who have a command of the foreign language would be needed to sustain these efforts.

On the other hand, learners' beliefs and assumptions about foreign language learning may undermine how they approach the course. For example, "knowing a language" is usually associated with speaking. Beliefs and assumptions like that need to be addressed and demonstrate that, in this case in point, speaking is one more form of communicating your views, not the only one.

This paper shared a change of approach to syllabus design for the development of scholarly academic competences in tertiary education. It is hoped that the insights and discussion derived from the analysis of this course experience will be pertinent to those dedicated to academic reading and to scholarly writing.

\section{References}

Bailey, S. (2011). Academic writing for undergraduate students: A Handbook for International Students ( $3^{\text {rd }}$ Ed.). London and New York: Routledge.

Castelló, M., Mateos, M., Castell, N., Iñesta, A., Cuevas I., \& Solé, I. (2012). Academic writing practices in Spanish universities. Electronic Journal of Research in Educational Psychology, 10(2), 569-590. Retrieved from: http://www.investigacion-psicopedagogica.org/revista/articulos/27/ english/Art_27_688.pdf

Castillo, R. (2014). Teaching and learning another language strategically. Bogotá: Universidad Distrital Francisco José de Caldas. Retrieved from http:// die.udistrital.edu.co/publicaciones/teaching_and_learning_another_language_strategically

Castillo, R., \& Pineda-Puerta, A. (2016). The illusio of the foreign language standard in a Colombian university. Latin American Journal of Content and Language Integrated Learning, 9(2), 426-450. doi: 10.5294/ laclil.2016.9.2.8. 
Cope, B., \& Kalantzis, M. (2009). 'Multiliteracies': New literacies, new learning. Pedagogies 4(3), 164-195. Retrieved from: http://newlearningonline.com/files/2009/03/M-litsPaper13Apr08.pdf

Devitt, A. J. (2015). Genre performances: John Swales' genre analysis and rhetorical-linguistic genre studies. Journal of English for Academic Purposes, 19, 44-51. doi: 10.1016/j.jeap.2015.05.008

Digital tools for researchers. (2017). Retrieved from: http://connectedresearchers.com/online-tools-for-researchers/

Eisner, C. (2012, February 27). Writing the research statement: How and why you research what you do [Blog post]. Retrieved from http:// www.academiccoachingandwriting.org/academic-writing/academic-writing-blog/vi-writing-the-research-statement-how-and-whyyou-research-what-you-do/

Elwel, F. (2013). Glossary of the social sciences. Retrieved from http://www. faculty.rsu.edu/users/f/felwell/www/glossary/Index.htm

Granados, C. (2013). Challenges of bilingualism in higher education: Experience of the Languages Department at the Universidad Central in Bogotá, Colombia. GIST Education and Learning Research Journal, (7), 245-258.

Hyland, K. (2007). Genre pedagogy: Language, literacy and L2 writing. Journal of Second Language Writing, 16, 148-164. Retrieved from http://www2. caes.hku.hk/kenhyland/files/2010/12/Hyland-genre-teaching.pdf

Hyland, K. (2004). Genre and second language writing. Ann Arbor, MI: University of Michigan Press.

Ibáñez, R. (2007). Comprensión de textos disciplinares escritos en inglés. Revista de Lingüística Teórica y Aplicada, 45(1), 67-85.

Iyer, R. (2007). Pedagogies of design and multiliterate learner identities. The International Journal of Learning 13, 25-34. Retrieved from http:// eprints.qut.edu.au/7422/1/7422.pdf

Kent, T. (2012). Post-process Theory: Beyond the writing-process paradigm. Carbondale and Edwardsville: Southern Illinois University Press.

Klimova, B. F. (2011). Making academic writing real with ICT. Procedia Computer Science, 3, 133-137.

Marshall, S. (2007). Engagement Theory, WebCT, and academic writing in Australia. International Journal of Education and Development using ICT, 3(2). Retrieved from http://ijedict.dec.uwi.edu/viewarticle. php?id=227 
Microsoft (2018). APA, MLA, Chicago - automatically format bibliographies. Retrieved from: https://support.office.com/en-us/article/APA-MLA-Chicago-\%E2\%80\%93-automatically-format-bibliographies-405c207c-70 70-42fa-91e7-eaf064b14dbb

M.E.N (2015). Programa Nacional de inglés 2015-2025: Colombia very well. Retrieved From: http://www.colombiaaprende.edu.co/html/micrositios/1752/articles-343287_recurso_1.pdf

O'Malley, J. M., \& Chamot, A. U. (1990). Learning strategies in second language acquisition. Cambridge: Cambridge University press.

Oxford, R. (1990). Language learning strategies: What every teacher should know. Boston, MA: Newbury House Publisher.

Oxford, R. (2013). Teaching \& researching: Language learning strategies. London and New York: Routledge.

Piedrahíta, D. (2010). Normas APA en Microsoft Word 2010. Retrieved from http://www.youtube.com/watch?v=uGgpzRxMvGA

Pechakucha. (n.d).The art of concise presentations. Retrieved from http:// www.pechakucha.org/

Peretz, A. (2005). "Teaching Scientific/Academic Writing in the Digital Age" The Electronic Journal of e-Learning. 3 (1) 55-66

Purdue University (2014). Online Writing Lab. Available at: https://owl.english.purdue.edu/owl/

Simon Fraser University Library. (2007). Thesis Templates. Retrieved on February 10, 2015 from: http://www.lib.sfu.ca/help/writing/thesis/ templates.

Swales, J. M. (1990). Genre analysis: English in academic and research settings. Cambridge: Cambridge University Press.

Swales, J. M. (2004). Research Genre: Explanations and Applications. Cambridge: Cambridge University Press.

Swales, M., \& Feak, C. B. (2010).Academic writing for Graduate Students: Essential Tasks and Skills. A Course for Nonnative Speakers of English. Ann Arbor: University of Michigan Press.

The Education University of Hong Kong. (2016). Video Resources for Doctoral Students. Accessed from: https://iell.web.ied.edu.hk/InternationalEducator/tablet.html

Trenado, P. (2004). El entrenamiento estratégico en el aula de L2: Fundamentos, fases y modelos. Retrieved Feb 17, 2016 from: http://www. kandagaigo.ac.jp/kuis/aboutus/pdf/paloma_trenado.pdf. 
University of Nevada Writing Center (2014). Retrieved from:

http://www.unr.edu/writing-center

University of Southern California. (2017). Organizing Your Social Sciences Research Paper. Retrieved Jan 10, 2017. http://libguides.usc.edu/ writingguide/purpose

University of Virginia. (2014). Problem statement template. Retrieved August 1, 2013 from: http://faculty.virginia.edu/schoolhouse/WP/probstattemplate.html

Visuwords. A visual dictionary and a visual thesaurus with interactive lexicon. Accessed from https://visuwords.com/

Wordle. (2016). Beautiful word clouds. Accessed from: http://www.wordle.net/ Wordsift. (2017). Accessed from: https://wordsift.org/ 


\section{Appendix 1.}

Commented List of ICT Resources Employed (in alphabetical order)

Dictionaries of Collocations identify common word combinations which constitute building blocks of natural-sounding English. Excellent for composing and for enhancing vocabulary use.

Glossaries assisted learners in understanding commonly used terms and concepts Elwell (2013), and University of Southern California (2017). Task 2 and task 5 of Table 1 and of the Appendix drew from consulting glossaries.

Graphic organizers like a Venn diagram, a time line or a flowchart assisted graduates in constructing or deconstructing meaning and in self-assessing understanding.

MSWord. Graduates set the word processor to the FL. For working in two languages, they divided the MSWord processor sheet into two columns, one for the original language and the other for the FL. This allows efficient editing and monitoring. In addition, the syllabus involved guides and tasks for generating references and citations with the word processor in English (Microsoft, 2018) and for Spanish (Piedrahita, 2010).

On-line translators proved useful in composing.

On-screen correction allowed ease of administration, facilitated quality feedback, and promoted self-evaluation and peer evaluation.

PechaKucha (pechakucha.org) helped prepare oral presentations by planning a 20 -slide presentation, with little text, for delivery in six minutes and 40 seconds that is 20 seconds per slide. Writing the script and rehearsing gave them confidence.

Ted Conferences at Ted.com is a platform to spread ideas in many disciplies.

Templates for academic purposes. Simon Fraser University (2007), Eisner (2012) and The University of Virginia (2014) templates proved useful for a controlled task to write the problem statement.

Text-to-Speech tools read aloud a text that is copied and pasted. It was used it to listen to their written drafts and rehearse presentations.

The Education University of Hong Kong (2016). An on-line repository of resources for doctoral students. It contains five volumes with 
several videos that cover the research process with voices from doctoral students and supervisors.

University of Southern California (2017) provides a library guide for social science writing. Students affirmed they used them as checklists: In fact, the rubrics developed for the course tasks and assign2 and of the Appendix.

Video-conferences such as those found in YouTube and academic websites. Multimodality built learners' understanding and self-assurance; for instance, scripts and subtitles facilitated comprehension and increased motivation.

Visuwords. A visual dictionary in which graphs associate words and expand on concepts.

Word clouds are free tools that visually represent a text based on the frequency of occurrence of a word. Word clouds aided to identify the key concepts of a text. In the sample in Table 1 and in the Appendix, the word cloud appears in Task 1. Wordle (2016) and Wordsift (2017) aided editors for drafts. With the cloud, writers spotted words that they overused.

Writing centers/labs. University of Nevada Writing Center (2014), and Purdue Writing Lab (2014) and many others offer tips and samples of sentences and structure, on general writing, on report writing, on APA style, on citations and referencing among others.

The above is a sample of tools, by no means exhaustive, that are readily available and that were applied. Digital tool for researchers (2017) offers a large inventory. The course tasks and procedures that appear next illustrate the dynamics of the class and of the independent work carried out. 


\section{Appendix 2.}

Sample of a B1 level Student's work (His language use is unedited).

The rubrics illustrate the procedure and the exploitation of digital tools. His topic: Circulation of the theory of biological evolution in primary and secondary schools in Colombia.

Note: The original draft has been shortened for the sake of brevity. Feedback was provided on screen and with tracking changes for resubmission.

Task A. Copy and paste the current title and introduction of your thesis in Wordle.net (except the reference section) in the original language.

Title of thesis: Circulation of the theory of biological evolution in primary and secondary education in Colombia.

Orignal title: Circulación de la teoría de la evolución biológica en la educación primaria y secundaria de Colombia.

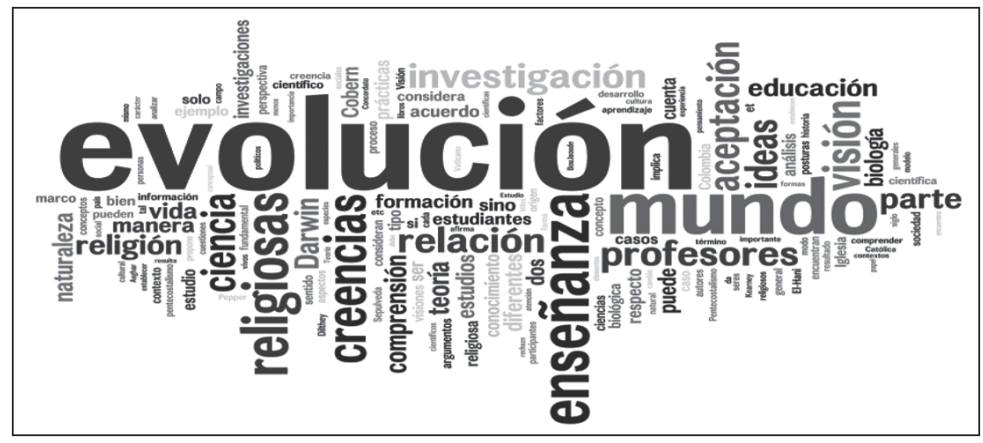

\section{Task B.}

From the cloud generated with Wordle, select ten key words. Translate them into English and find its definition in an on-line dictionary.

Evolution: a theory that the differences between modern plants and animals are because of changes that happened by a natural process over a very long time (Webster dictionary).

Religious belief: is the belief in the reality of the mythological, supernatural, or spiritual aspects of a religion. Religious belief is distinct from religious practice or religious behaviours with some believers not practicing religion and some practitioners not believing religion. (Wikipedia)

A strong belief in a supernatural power or powers that control human destiny (The free dictionary) 
Comprehend: to grasp the nature, significance, or meaning of...

Belief: A feeling of trust in the worth or ability of someone. (Webster dictionary).

Belief is the psychological state in which an individual holds a conjecture or premise to be true. Dispositional and concurrent belief concerns the contextual activation of the belief into thoughts (reactive of propositions) or ideas (based on the belief's premise). (Wikipedia).

World view: the way someone thinks about the world: weltanschauung. A comprehensive conception or apprehension of the world especially from a specific standpoint.

German, from Welt world + Anschauung view. First Known Use: 1868. (Webster dictionary).

Acceptance: Acceptance is fundamental to the core dogma of most Abrahamic religions, the MSWord "Islam" can be translated as "acceptance", "surrender" or "voluntary submission" and Christianity is based upon the "acceptance" of Jesus of Nazareth as the "Christ" and could be compared to some Eastern religious concepts such as Buddhist mindfulness. (Wikipedia)

Religion: The belief in a god or in a group of gods. An organized system of beliefs, ceremonies, and rules used to worship a god or a group of gods. An interest, a belief, or an activity that is very important to a person or group. (Webster dictionary).

\section{Tasks C and D.}

Temporarily customize the tool Scholar.google.com. Select English. Then enter the ten key words to search for documents related to your thesis. Using an on-line translator, when necessary, build a glossary of other key terms.

Theory: An idea or set of ideas that is intended to explain facts or events. The general principles or ideas that relate to a particular subject. (Webster dictionary).

Science education: Science education is the field concerned with sharing science content and process with individuals not traditionally considered part of the scientific community... (Wikipedia).Culture: (Latin: cultura, lit. "Cultivation") is a modern concept based on a term first used in classical antiquity by the Roman orator Cicero: "cultura animi" (cultivation of the soul). This non-agricultural use of the term "culture" re-appeared in modern Europe in the 17th century referring to the betterment or refinement of individuals, especially through education. During the 18th 
and 19th century it came to refer more frequently to the common reference points of whole peoples, and discussion of the term was often connected to national aspirations or ideals.... (Wikipedia)

Social context: The social environment, social context, sociocultural context, or milieu, refers to the immediate physical and social setting in which people live or in which something happens or develops...

Creationism: a doctrine or theory holding that matter, the various forms of life, and the world were created by God out of nothing and usually in the way described in Genesis...

(Wikipedia).

Fundamentalism: a movement in 20th century Protestantism emphasizing the literally interpreted Bible as fundamental to Christian life and teaching. (Wikipedia).

Science: knowledge about or study of the natural world based on facts learned through experiments and observation. A particular area of scientific study (such as biology, physics, or chemistry): a particular branch of science. (Webster dictionary).

Research: The primary purposes of basic research (as opposed to applied research) are documentation, discovery, interpretation, or the research and development (R\&D) of methods and systems for the advancement of human knowledge. There are several forms of research: scientific, humanities, artistic, economic, social, business, marketing, practitioner research, etc. (Wikipedia).

Biology: Is a natural science concerned with the study of life and living organisms, including their structure, function, growth, evolution, distribution, and taxonomy... (Wikipedia)

Nature: The physical world and everything in it (such as plants, animals, mountains, oceans, stars, etc.) that is not made by people. The natural forces that control what happens in the world. The way that a person or animal behaves the character or personality of a person or animal. (Webster dictionary).

Curriculum: the courses offered by an educational institution: a set of courses constituting an area of specialization. (Webster dictionary).

Conception: The capacity, function, or process of forming or understanding ideas or abstractions or their symbols. A complex product of abstract or reflective thinking. The sum of a person's ideas and beliefs concerning something. (Webster dictionary). 
Factor: something that helps produce or influence a result: one of the things that cause something to happen. (Webster dictionary).

Pseudoscience: is a claim, belief or practice, which is presented as scientific, but does not adhere to a valid scientific method, lacks supporting evidence or plausibility, cannot be reliably tested, or otherwise lacks scientific status. ... (Wikipedia).

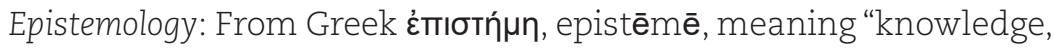
understanding", and $\lambda$ óyos, logos, meaning "study of") is the branch of philosophy concerned with the nature and scope of knowledge, and is also referred to as "theory of knowledge". It questions what knowledge is and how it can be acquired, and the extent to which knowledge pertinent to any given subject or entity can be acquired. Much of the debate in this field has focused on the philosophical analysis of the nature of knowledge and how it relates to connected notions such as truth, belief, and justification... (Wikipedia).

The study or a theory of the nature and grounds of knowledge especially with reference to its limits and validity. (Webster dictionary).

Specie: In biology, a species (plural: species) is one of the basic units of biological classification and a taxonomic rank. A species is often described as the largest group of organisms capable of interbreeding and producing fertile offspring. While in many cases this definition is adequate, the difficulty of defining species is known as the species problem. Differing measures are often used, such as similarity of DNA, morphology, or ecological niche. (Wikipedia).

\section{Task E.}

Draft an abstract of your thesis using the above glossary and the guide found at: http://libguides.usc.edu/writingguide/abstract

Before submitting the abstract, proofread and edit with the grammar-spelling check and with Wordle.

Abstract.

The project deals with the relationship between the religious beliefs and the evolution teaching. The evolution is a conceptual system and an intellectual movement. For this reason to understand its origin, development, and circulation is important tackle the social and cultural context. The evolution education deals with the different kind of ideas, for example the religious beliefs. The study proposes a research on the relations between the teacher's religious belief and your teach- 
ing practice. Several reports of research have found that the belief has a strong influence on the evolution acceptance and that this influences the teaching. In Colombia don't exist research about it. Finally, the study proposes development some recommendations to the initial biology teacher training based on the findings of own research and a documental review.

\section{Task F.}

Using the concepts gathered in the articles found in the university academic databases as well as in other sources, please draft in English an introduction to your thesis. http://libguides.usc.edu/writingguide/ introduction

Introduction.

This document exposes a Doctoral thesis project that deals about the relationship between the religious beliefs and the evolution teaching. The purpose of project is to develop a deep and fine comprehension about the evolution teach practices of two biology secondary teachers on relation with the religious belief of them. Based on the own findings and a documental review we will propose several contents to tackle in the initial biology teacher training.

To write this project we made a wide documental review and we found few detailed studies about the relations between the religious beliefs and the evolution education. Most researches are quantitative. A few studies make investigation into the classroom. For these reasons, we propose this investigation.

The proposal is oriented by the idea that the teaching happens in a political, cultural, social and economic context, and this is very important to understand the teaching. About the religious beliefs, we think that they are more than a motivational factor. In certain circumstances, the beliefs configure a particular way or framework to understand the world.

The first part of the document exposes the problem of research and the justification. After it shows the objectives and the literature review. The theoretical framework presents very important subjects to the research: the evolution education problems, the positions about the relationship between science and religion, the history of the scientific evolution idea and that it imply to teaching, the Colombian religious context, and finally and brief expose about the "world view" 
theory. The methodology presents the main perspectives and some ethical considerations.

Finally, it's worth noting that we use the MSWord "evolution" to refer us to the "biological evolution". We don't use "evolution theory" due to is confused because the evolution are a theoretical body, composed by many theories. No way has the use of MSWord "evolution" or "biological evolution" denied the scientific character of her.

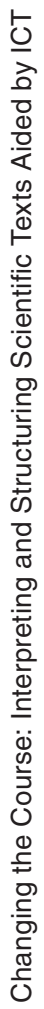

